\title{
On the occasion of world kidney day 2018 with the theme of kidney disease in women; vitamin D deficiency and kidney diseases in women
}

\author{
Mohammad Reza Tamadon* \\ Department of Internal Medicine, Semnan University of Medical Sciences, Semnan, Iran
}

\section{A R T I C L E I N F O}

Article Type:

Epidemiology and Prevention

\section{Article History:}

Received: 9 May 2017

Accepted: 8 September 2017

Published online: 14 September 2017

\section{Keywords:}

Vitamin D, Vitamin D deficiency

Hypovitaminosis D, Osteomalacia

Vitamin D inadequacy,

Parathormone,

1,25-dihydroxyvitamin D3
Implication for health policy/practice/research/medical education:

Vitamin D is known as a distinctive hormone made in the skin from exposure to sunshine. 1,25-dihydroxyvitamin D3 can stimulate the absorption of intestinal calcium by $30 \%-40 \%$ and phosphorus by $80 \%$. Moreover, it increases the absorption of minerals from the skeletal system. Vitamin D deficiency decreases the absorption of dietary calcium and phosphorus from the intestine and subsequently, leads to an increase in the levels of PTH. Here are some studies on the prevalence of vitamin D deficiency in women.

Please cite this paper as: Tamadon MR. On the occasion of world kidney day 2018 with the theme of kidney disease in women; vitamin D deficiency and kidney diseases in women. J Renal Inj Prev. 2018;7(1):33-34. DOI: 10.15171/jrip.2018.07.

\section{Introduction}

Vitamin $\mathrm{D}$ is known as a distinctive hormone made in the skin from exposure to sunshine $(1,2)$. Two significant types of vitamin D include vitamin D2 (ergocalciferol) and vitamin D3 (cholecalciferol). Vitamin D3 proven as an influential type of vitamin $\mathrm{D}$ is synthesized from 7-dehydrocholesterol exposed to sunshine in the skin (1). Vitamin D 25-hydroxylase invert vitamin D to $25(\mathrm{OH}) \mathrm{D}$ by hydroxylation in the liver $(1,3)$. Subsequently, $25(\mathrm{OH})$ $\mathrm{D}$-1 $\alpha$-OHase invert $25(\mathrm{OH}) \mathrm{D}$ to the biologically active form of vitamin $\mathrm{D}, 1,25(\mathrm{OH}) 2 \mathrm{D}$, by a further hydroxylation in the kidneys. Accordingly, 1,25(OH)2D acts by binding with its nuclear receptor in the different tissues including small intestine, kidneys and osteoblasts. Additionally, $1,25(\mathrm{OH}) 2 \mathrm{D}$ can stimulate the absorption of intestinal calcium by $30 \%-40 \%$ and phosphorus by $80 \%$ (4). It can also increase calcium reabsorption from the kidneys $(1,5)$. Moreover, it increases the absorption of minerals from the skeletal system and modifies osteoblastogenesis and osteoclastogenesis. Since the main thing from which vitamin $\mathrm{D}$ can be obtained is exposure to sunshine, the main reason for vitamin D deficiency is insufficient exposure to sunlight $(2,6)$. Wearing sunscreen, people with dark skin, obesity, fat malabsorption syndrome in which patients are not able to absorb the fat-soluble vitamin $\mathrm{D}$, and nephrotic syndrome are significant factors associated with vitamin $\mathrm{D}$ deficiency $(1,7)$. Vitamin $\mathrm{D}$ deficiency decreases the absorption of dietary calcium and phosphorus from the intestine and subsequently, leads to an increase in the levels of parathormone (PTH). Secondary hyperparathyroidism leads to calcium modification through increased absorption of calcium from the skeleton and increased phosphorus excretion in the kidneys $(1,4,8)$. Low levels of blood phosphorus induced by secondary hyperparathyroidism can cause mineralization defect in the skeleton known as rickets in children and osteomalacia in adults (9). Muscle weakness is another result of vitamin $\mathrm{D}$ deficiency that increases the risk of fractures (10). The levels of serum 25-hydroxyvitamin D determined for vitamin D deficiency and vitamin $\mathrm{D}$ insufficiency are respectively less than 20 $\mathrm{ng} / \mathrm{mL}$ and $21-29 \mathrm{ng} / \mathrm{mL}(1,4)$. According to statistics, $48 \%$ of white preschool girls in Maine had less than $20 \mathrm{ng} / \mathrm{mL}$ 25(OH)D (11). Furthermore, $42 \%$ of African-American women at age of 15-49 in the United States had serum level of less than $15 \mathrm{ng} / \mathrm{mL} 25(\mathrm{OH}) \mathrm{D}$ at the beginning of the spring (12). In addition, taking vitamin and calcium supplement with vitamin $\mathrm{D}$ by women during pregnancy and lactation did not decrease the risk of vitamin D deficiency and 
higher-dose supplementation was needed (13). One study on the prevalence of vitamin D deficiency in pregnant women from different ethnic backgrounds living in the Netherlands demonstrated very high outbreak of vitamin D deficiency in pregnant non-Western women (14). Another study on the outbreak of hypovitaminosis D in women in pregnancy and their babies also showed a significant vitamin D deficiency among studied groups. Moreover, this study demonstrated a positive communication between maternal serum $25(\mathrm{OH}) \mathrm{D}$ and cord blood $25(\mathrm{OH}) \mathrm{D}$ and inverse communication between maternal serum $25(\mathrm{OH}) \mathrm{D}$ and PTH (15). Lips et al (8) investigated the prevalence of vitamin $\mathrm{D}$ inadequacy amongst 2606 women with a mean age of $67.1 \pm 7.7$ years suffering from osteoporosis. The results showed serum $25(\mathrm{OH}) \mathrm{D}$ levels less than $30 \mathrm{ng} / \mathrm{mL}$ in $63.9 \%$ of women. Therefore, $63.9 \%$ of women suffering from osteoporosis had vitamin D inadequacy. Vitamin $\mathrm{D}$ inadequacy was not related to older age and whether or not women were receiving osteoporosis treatment. In addition, taking vitamin D supplement $\geq 400$ IU every day decreased the outbreak of vitamin $\mathrm{D}$ inadequacy in women. Generally, this study demonstrated that serum 25(OH)D levels are commonly low among women suffering from osteoporosis. According to a trial, the intake of vitamin $\mathrm{D}$ and calcium supplement by women without history of diabetes during 20 years decreased the risk of type 2 diabetes (16). Moreover Milaneschi and colleagues (17) suggested that vitamin D inadequacy is a risk factor for the advancement of depressive signs in old people. This association in women is stronger than men. These finding shed a light to vitamin D deficiency in women. Vitamin $\mathrm{D}$ deficiency may predispose women to renal diseases or aggravate renal insufficiency too.

\section{Authors' contribution}

MRT is the single author of the manuscript.

Conflicts of interest

The author declares no conflict of interest.

\section{Ethical considerations}

Ethical issues (including plagiarism, data fabrication, double publication) have been completely observed by the author.

\section{Funding/Support}

None.

\section{References}

1. Holick MF. Vitamin D deficiency. N Engl J Med. 2007; 357:266-81.

2. Moan J, Porojnicu AC, Dahlback A, Setlow RB. Addressing the health benefits and risks, involving vitamin D or skin cancer, of increased sun exposure. Proc Natl Acad Sci USA.
2008;105:668-73.

3. DeLuca H. Overview of general physiologic features and functions of vitamin D. Am J Clin Nutr. 2004;80:1689S-96S.

4. Heaney RP. Functional indices of vitamin D status and ramifications of vitamin D deficiency. Am J Clin Nutr. 2004;80:1706S-1709S.

5. Dusso AS, Brown AJ, Slatopolsky E. Vitamin D. Am J Physiol Renal Physiol. 2005;289:F8-F28.

6. Looker AC, Pfeiffer CM, Lacher DA, Schleicher RL, Picciano MF, Yetley EA. Serum 25-hydroxyvitamin D status of the US population: 1988-1994 compared to 2000-2004. Am J Clin Nutr. 2008;88:1519-27.

7. Hintzpeter B, Scheidt-Nave C, Müller MJ, Schen kL, Mensink GB. Higher prevalence of vitamin D deficiency is associated with immigrant background among children andadolescents in Germany. J Nutr. 2008;138:1482-490.

8. Lips P, Hosking D, Lippuner K, Norquist JM, Wehren L, Maalouf G, et al. The prevalence of vitamin D inadequacy amongst women with osteoporosis: an international epidemiological investigation. J Intern Med. 2006;260:24554.

9. Gordon CM, Williams AL, Feldman HA, May J, Sinclair L, Vasquez A, Cox JE. Treatment of hypovitaminosis D in infants and toddlers. J Clin Endocrinol Metab. 2008; 93:2716-21.

10. Bischoff-Ferrari H, Dawson-Hughes B, Staehelin HB, Orav JE, Stuck AE, Theiler R, et al. Fall prevention with supplemental and active forms of vitamin D: a meta-analysis of randomised controlled trials. BMJ. 2009;339:b3692.

11. Sullivan SS, Rosen CJ, Halteman WA, Chen TC, Holick MF. Adolescent girls in Maine at risk for vitamin D insufficiency. J Am Diet Assoc. 2005;105:971-974.

12. Nesby-O’Dell S, Scanlon KS, Cogswell ME, Gillespie C, Hollis BW, Looker AC, et al. Hypovitaminosis D prevalence and determinants among African American and white women of reproductive age: Third National Health and Nutrition Examination Survey, 1988-1994. Am J Clin Nutr. 2002;76:187-92.

13. Bodnar LM, Simhan HN, Powers RW, Frank MP, Cooperstein E, Roberts JM. High prevalence of vitamin D insufficiency in black and white pregnant women residing in the northern United States and their neonates. J Nutr. 2007;137:447-52.

14. van der Meer IM1, Karamali NS, Boeke AJ, Lips P, Middelkoop BJ, Verhoeven I, et al. High prevalence of vitamin $\mathrm{D}$ deficiency in pregnant non-Western women in The Hague, Netherlands. Am J Clin Nutr. 2006;84:350-3.

15. Sachan A, Gupta R, Das V, Agarwal A, Avasthi PK, Bhatia $\mathrm{V}$. High prevalence of vitamin D deficiency among pregnant women and their newborns in northern India. Am J Clin Nutr. 2005;81:1060-4.

16. Pittas AG, Dawson-Hughes B, Li T, Van Dam RM, Willett WC, Manson JE, et al. Vitamin D and Calcium Intake in Relation to Type 2 Diabetes in Women. Diabetes Care. 2006;29:650-6.

17. Milaneschi Y, Shardell M, Corsi AM, Vazzana R, Bandinelli S, Guralnik JM, et al. Serum 25-Hydroxyvitamin D and Depressive Symptoms in Older Women and Men. J Clin Endocrinol Metab. 2010;95:3225-33. doi: 10.1210/jc.20100347.

Copyright (C) 2018 The Author(s); Published by Nickan Research Institute. This is an open-access article distributed under the terms of the Creative Commons Attribution License (http://creativecommons.org/licenses/by/4.0), which permits unrestricted use, distribution, and reproduction in any medium, provided the original work is properly cited. 